\title{
Growth regime and environmental remediation of microalgae
}

\author{
Ademola Monsur Hammed ${ }^{1}$, Sanjeev Kumar Prajapati ${ }^{2}$, Senay Simsek ${ }^{3}$ and Halis Simsek ${ }^{4, *}$ \\ ${ }^{1}$ International Institute of Halal Research and Training, International Islamic University, Gombak Selangor, 53100, \\ Malaysia \\ ${ }^{2}$ Biochemical Engineering and Bioenergy Lab, Division of Biotechnology, Netaji Subhas Institute of Technology, \\ New Delhi 110078, India \\ ${ }^{3}$ Department of Plant Sciences, North Dakota State University, Fargo, ND 58102, USA \\ ${ }^{4}$ Department of Agricultural \& Biosystems Engineering, North Dakota State University, Fargo, ND 58102, USA
}

Microalgal bioremediation of $\mathrm{CO}_{2}$, nutrients, endocrine disruptors, hydrocarbons, pesticides, and cyanide compounds have evaluated comprehensively. Microalgal mitigation of nutrients originated from municipal wastewaters, surface waters, and livestock wastewaters has shown great applicability. Algal utilization on secondary and tertiary treatment processes might provide unique and elegant solution on the removing of substances originated from various sources. Microalgae have displayed 3 growth regimes (autotrophic, heterotrophic, and mixotrophic) through which different organic and inorganic substances are being utilized for growth and production of different metabolites. There are still some technology challenges requiring innovative solutions. Strain selection investigation should be directed towards identification of algal that are extremophiles. Understanding and manipulation of metabolic pathways of algae will possible unfold solution to utilization of algae for mitigation of dissolve organic nitrogen in wastewaters.

Key Words: bioremediation; microalgae; nutrient removal; wastewater

\section{INTRODUCTION}

Bioremediation is a human-engineered process which involves use of microorganism to remove or metabolize toxic, mutagenic, and carcinogenic substances to nontoxic compounds. Bioremediation has been recognized as efficient, cost effective, and a suitable alternative to conventional methods for removing contaminant (Mandal et al. 2012). Efficiency of bioremediation depends on the type of microorganism being used and is greatly affected by the environmental conditions. Based on their inherent biological characteristics, different microorganisms metabolize substance at different degree and have been used for bioremediation process. There are several reports available in the literature targeting bioremediation of wastewater by use of fungi (Mishra and Malik 2013, Kaushik and Malik 2015), bacteria (Wasi et al. 2013), and microalgae (Prajapati et al. 2013a). In contrast to other organism, microalgae are unique to have the ability to do photosynthesis like plant and to utilize organic / inorganic carbon substrate, the process termed as phycoremediation. Microalgae can populate reaction site quickly and enhance bio-remediation efficiency. Photosynthetic ability of microalgae makes them suitable for $\mathrm{CO}_{2}$ mitigation. Moreover, microalgae proliferate in wastewater by utilizing the essential nutrients especially nitrogen and
(9) $\$$ This is an Open Access article distributed under the terms of the Creative Commons Attribution Non-Commercial License (http://creativecommons.org/licenses/by-nc/3.0/) which permits unrestricted non-commercial use, distribution, and reproduction in any medium, provided the original work is properly cited.
Received February 24, 2016, Accepted August 28, 2016

*Corresponding Author

E-mail: halis.simsek@ndsu.edu

Tel: +1-701-231-6107, Fax: +1-701-231-1008 
phosphorous compounds present in the wastewater.

Microalgae have been reported to utilize several compounds, including pesticides, hydrocarbons, endocrine disruptors, and cyanides as carbon and nitrogen sources. In addition, microalgal cell wall is made up of carbohydrate structures capable of bio-absorption of toxic chemical agents in wastewater. Therefore, microalgae are potentially suitable for mitigation of several compounds including nitrogen, phosphorous, heavy metals, and other polluting compounds in wastewaters. Proper management of microalgal bioremediation in aquatic ecosystem is crucial since controlled microalgal treatment successfully remove the nutrients from numerous sources including; domestic and industrial wastewater discharges, livestock and poultry feedlots, atmospheric deposition, surface runoff from agricultural lands that use animal manure and inorganic fertilizers as a nutrient source, and other natural and anthropogenic sources. Improper land applications and storage of solid and slurry manure have a profound effect on the environment since they enhance nutrient transportation to aquatic systems. Therefore, it can be explained that nutrients that originated from domestic and livestock wastewaters are the most important $\mathrm{N}$ sources in receiving waters and its reduction are crucial for especially nutrient sensitive surface waters. Microalgae, having ability to grow mixotrophically, are efficiently used for remediation wastewater which is rich in inorganic and organic nutrients and substrates.

The degradation of environment reduces the quality of life and may cause several disease including cancer on human being (Ferrer-i-Carbonell and Gowdy 2007). In order to combat this problem, researchers have mapped out numerous strategies involving (1) identification and / or mitigation of factors that exhibit negative environmental impact and (2) development and / or improvement of alternative activities that are environmentally friendly. Among numerous alternative approaches and controlled measures, bio-remediation has been identified as one of the most viable and feasible environmental control measure.

Many review works have focused on different roles of microalgae for environmental remediation. For instance, Wang et al. (2008) reviewed bio-mitigation of $\mathrm{CO}_{2}$ by microalgae, Yang et al. (2015) reviewed microalgae growth under anoxic and hypoxic conditions, Wang et al. (2014) reviewed microalgae cultivation in photobioreactor, Singh and Singh (2014) reviewed effect of $\mathrm{CO}_{2}$ on microalgal growth potential. Recently, there has been tremendous growth in works related to this area of research thus initiated this review work that will serve as a comprehen- sive update and quick reference material. In this work, we have concisely put together several research achievements and gaps that are widely spread among literatures.

\section{MICROALGAE GROWTH REGIMES}

Different species of microalgae can undergo autotrophic (photosynthesis), heterotrophic (substrate dependent) and / or mixotrophic (auto and heterotrophic) modes of nutrition depending on availability of organic carbon (substrate), $\mathrm{CO}_{2}$, and light (Fig. 1). Microalgae can also evolve to become specialized autotrophs or heterotrophs through long-term shifts in the growth conditions (Liang et al. 2009, Bell 2013). Microalgae contain multiple metabolic pathways for different growth regimes. Some microalgae can switch between these growth regimes (one is active while the other is inactive) at a particular period depending on the condition while other microalgae are capable of using the pathways simultaneously (Perez-Garcia et al. 2011). Presence of high concentration of $\mathrm{CO}_{2}$ enhances photosynthesis of microalgae but undermine utilization of organic carbon substrate possibly due to retardation of respiration. Besides, absence of light during dark cycles lead to utilization of organic carbon substrate (Sforza et al. 2012). Microalgae has exhibited diverse metabolic pathways when experiencing hypoxic (low $\mathrm{O}_{2}$ concentration) or anoxic (extremely low $\mathrm{O}_{2}$ concentration) conditions in aquatic system (Yang et al. 2015).

Understanding microalgal growth regimes tremendously helps in optimization studies on environmental remediation and metabolites production. Heterotrophic culturing of microalgae give room for treatment of wastewater containing carbon compounds while autotrophic culturing allows treatment of flue gas containing $\mathrm{CO}_{2}$. However, microalgae cultured under natural environment undergoes both; high rate of heterotrophic at night and autotrophic during the day. Some researchers have equally mimicked this process in photobioreactor by controlling provision of carbon substrate, light, and $\mathrm{CO}_{2}$ (Im et al. 2003, Xia and Gao 2005, Miazek et al. 2014).

\section{Heterotrophic growth regime}

Heterotrophic growth in microalgae is nonphotosynthetic / dark metabolism and involves utilization of organic carbon substrates for energy production and other metabolic activities (Morales-Sánchez et al. 2015). Heterotrophic culturing of microalgae is easier to operate, 


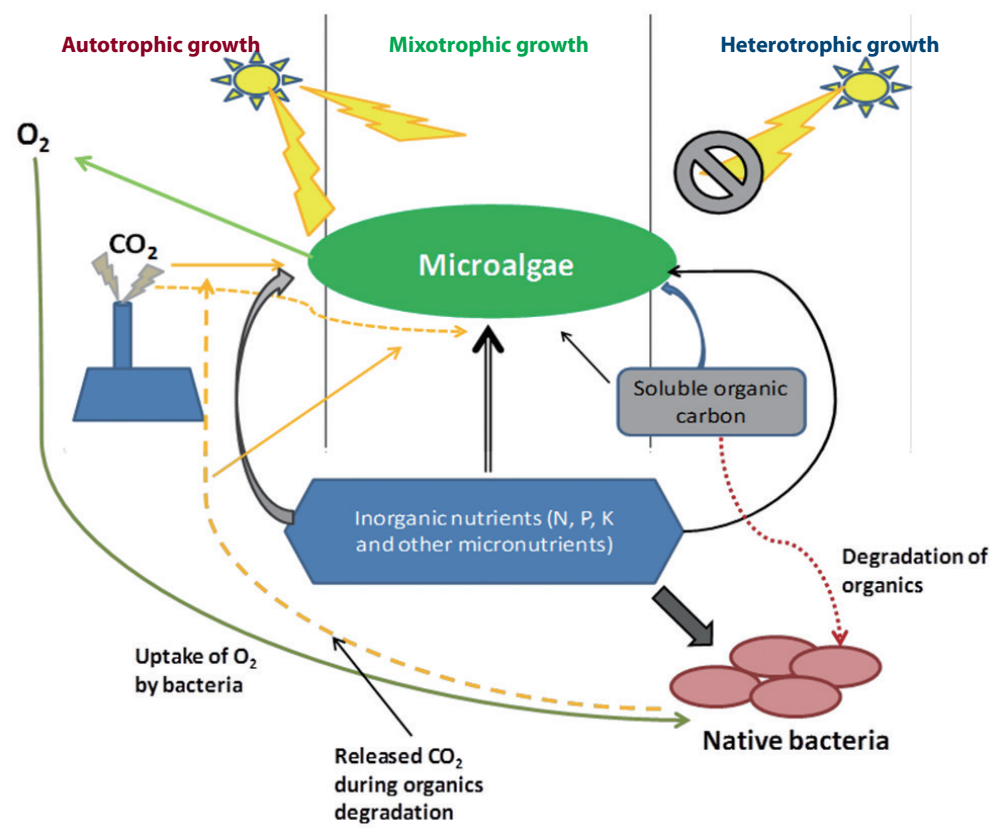

Fig. 1. Microalgal growth regimes under different environmental conditions.

produces increased cell mass, leads to high growth rates, produces high amounts of metabolites, enables monoculturing and low cost operation and construction of infrastructure (Perez-Garcia et al. 2011). The heterotrophic metabolic pathway entails three major steps: (1) uptake / assimilation, (2) activation and transformation, and (3) storage / utilization of metabolites (Morales-Sánchez et al. 2015). Uptake of carbon source like glucose requires symporter system-a cytoplasmic membrane bond protein (Morales-Sánchez et al. 2013) but other carbon sources (e.g., glycerol) do not as they easily diffuse into the cell (Perez-Garcia et al. 2011). Then carbon source undergoes glycolysis (Embden-Meyerhof pathway and pentose phosphate pathway), tricarboxylic acid cycle, and glyoxylate cycle pathways. The products are carbon skeleton metabolites such as fatty acid, intracellular polysaccharide, proteins, etc. The details of reactions flow / pathways are presented in Fig. 2. Microalgae used nitrogen for synthesis of amino acids during heterotrophic growth regime. Nitrogen sources for microalgae culturing are ammonium, nitrate, nitrite, urea and amino acids, peptone, purines, and yeast extract, etc. (Chen and Chen 2006). Ammonium is most preferred due to less energy is required for its uptake (Shi et al. 2000). However, several reports have shown that nitrate assimilation in microalgae is inhibited by factors like light (Morris 1974), presence of heavy metals above $150 \mu \mathrm{M}$ (Devriese et al. 2001) as well as presence of ammonium (Cannons and Pendle- ton 1994). Urea and other organic nitrogen compounds are also suitable for heterotrophic growth regime of microalgae. Hence, during the growth in wastewater which are rich in organics, probably dark in color and have ample inorganic nutrient present (e.g., agro industry based effluents), microalgae will show heterotrophic regime.

\section{Autotrophic growth regime}

Autotrophic growth of microalgae involves photosynthetic reduction cycle-light reaction, $\mathrm{CO}_{2}$ concentration, and dark reaction (Kruse et al. 2005). Briefly, microalgal pigments (chlorophylls, phycobilins, and carotenoids) absorb photon to generate electrons, which are transferred in to PSI, II and cytochrome b6f complexes, $\mathrm{ADP}^{+}$ and $\mathrm{NADP}^{+}$are converted to ATP and NADPH, respectively. The ATP and NADPH are used to drive biochemical reaction during the dark reaction for $\mathrm{CO}_{2}$ assimilation through Calvin Benson cycle in the chloroplast (Wang et al. 2014) (Fig. 2). The diffusion rate of $\mathrm{CO}_{2}$ in water and that from bicarbonate degradation in stroma is very low. Concentration of $\mathrm{CO}_{2}$ provides adequate amounts of $\mathrm{CO}_{2}$ to stroma in chloroplast and reduces $\mathrm{O}_{2}$ hindrance on ribulose-1,5-bisphosphate carboxylase / oxygenase (RuBisCO) (Nelson et al. 2008). Microalgae concentrate $\mathrm{CO}_{2}$ using carbonic anhydrase, inorganic carbon transporters, sequestered RuBisCOs in elevated $\mathrm{CO}_{2}$ microcompartment and carboxylation mechanisms (CAM and 


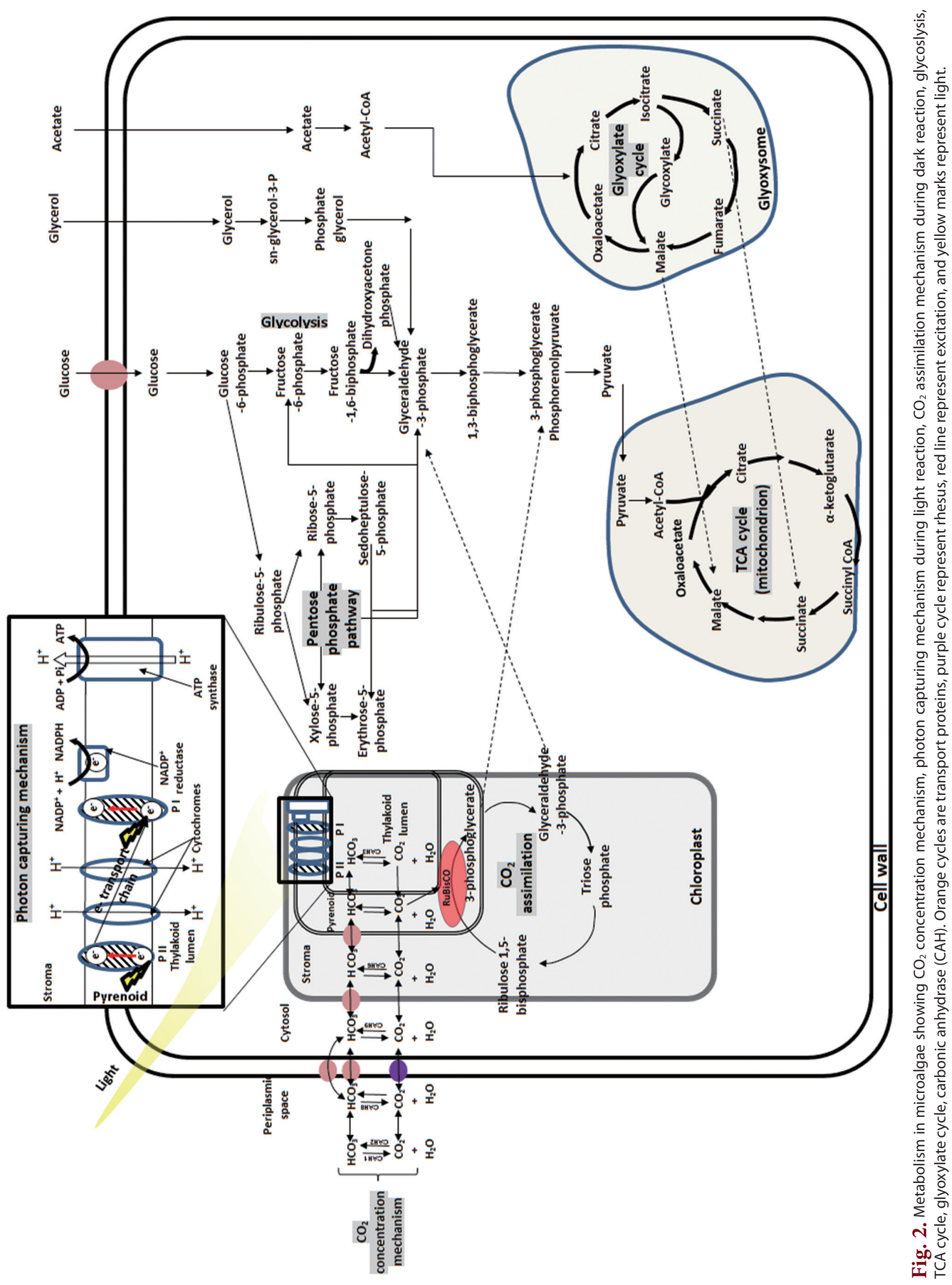


$\mathrm{C}_{4}$-photosynthesis) (Giordano et al. 2005, Wang et al. 2011, Baba and Shiraiwa 2012). Microalgal carbonic anhydrases (Table 1) are zinc-metalloenzymes responsible for rapid inter-conversion $\left(\mathrm{CO}_{2}+\mathrm{H}_{2} \mathrm{O} \leftrightarrow \mathrm{HCO}_{3}{ }^{-}+\mathrm{H}^{+}\right)$of inorganic carbon species (Moroney et al. 2011). Dissolved inorganic carbon transporters facilitate uptake of inorganic carbon and $\mathrm{CO}_{2}$ (Wang et al. 2011). Inorganic carbon transporters (Pollock et al. 2004, Ohnishi et al. 2010) include HLA3 at plasma membrane, LCIA at chloroplast membrane and CCP1 and 2 at chloroplast. Rhesus proteins also function as channels for $\mathrm{CO}_{2}$ in microalgae (Soupene et al. 2002) and that Rhesus-1 protein is a bidirectional channel for the $\mathrm{CO}_{2}$ in Chlamydomonas reinhardtii (Soupene et al. 2004). Several wastewaters, such as agricultural runoff, dairy farm effluents, and anaerobically digested manure are rich in inorganic nutrients but have low or no organic carbon (Prajapati et al. 2014a, Choudhary et al. 2015, 2016). For remediation of such wastewaters, addition of external carbon source is crucial, if microbes (other than microalgae), are being used. However, microalgae can efficiently remediate such wastewater without need of external carbon source as they can sequester $\mathrm{CO}_{2}$ from environment through autotrophic growth.

\section{Mixotrophic growth regime}

Range of wastewater contain adequate amount of both inorganic nutrients and biodegradable organic carbon source. In such wastewater, microalgae usually grow in mixotrophically. The mixotrophic growth regime involves simultaneous utilization of both inorganic and organic carbon substrate (Cerón-García et al. 2013). Mixotrophic microalgae have cellular apparatus for heterotrophic and autotrophic metabolism. Mixotrophic culture of microalgae resulted in higher growth rate, yield of metabolites, than auto- and hetero-trophic (Ogbonna et al. 2002, Das et al. 2011). A recent study has reported higher biomass production through mixotrphic microalgal growth wastewater supplemented with various carbon sources (Bhatnagar et al. 2011). Mixotropic is usually a complementary (Ogbonna et al. 2002, Fernández Sevilla et al. 2004) and a synergetic mechanism of auto- and heterotrophic (Cheirsilp and Torpee 2012). However, other researches have shown that microalgae generate higher energy in heterotrophic growth regime than in the case of mixotrophic condition (Yang et al. 2000, Hong and Lee 2007, Perez-Garcia et al. 2011). There are many internal controls and factors that regulate the rate at which each metabolic pathway proceeds. Microalgae respiration and photosynthesis activities are interconnected as cellular organelles communicate and exchange by-products (Yang et al. 2015), for instance (1) utilization of sugar / polysaccharide produced in chloroplasts through photosynthesis by mitochondria, (2) acquiring of ATP produce

Table 1. Locations and roles of carbonic anhydrase in microalgae

\begin{tabular}{|c|c|c|c|}
\hline $\begin{array}{l}\text { Carbonic } \\
\text { anhydrase }\end{array}$ & Location & Role & Reference \\
\hline$\alpha$-CAH1 & Periplasmic space & Facilitate the movement of $\mathrm{CO}_{2}$ across the plasma membrane & Moroney and Ynalvez (2007) \\
\hline$\alpha-\mathrm{CAH} 2$ & Periplasmic space & Facilitate the movement of $\mathrm{CO}_{2}$ across the plasma membrane & Moroney and Ynalvez (2007) \\
\hline$\alpha$-САНЗ & Thylakoid lumen & To provide $\mathrm{CO}_{2}$ to RuBisCO & Sinetova et al. (2012) \\
\hline$\beta-\mathrm{CAH} 4$ & Mitochondria & $\begin{array}{l}\text { Not known (but implicated in pH buffering in mitochondria } \\
\text { and in anapleurotic reactions) }\end{array}$ & Eriksson et al. (1998) \\
\hline$\beta$-CAH5 & Mitochondria & $\begin{array}{l}\text { Not known (but implicated in } \mathrm{pH} \text { buffering in mitochondria } \\
\text { and in anapleurotic reactions) }\end{array}$ & Eriksson et al. (1998) \\
\hline$\beta$-CAH6 & Chloroplast stroma & $\begin{array}{l}\text { Recapturing } \mathrm{CO}_{2} \text { effluxes from the thylakoid lumen and in } \\
\text { helping to maintain a high concentration of inorganic } \\
\text { carbon in the stroma }\end{array}$ & Mitra et al. (2004) \\
\hline$\beta$-CAH7 & Chloroplast & Not known & Moroney and Ynalvez (2007) \\
\hline$\beta$ - САH8 & Periplasm & Facilitate entering of inorganic carbon into cell & Moroney and Ynalvez (2007) \\
\hline $\beta$-САH9 & Cytoplasm & Enhance $\mathrm{CO}_{2}$ accumulation in the cytoplasm & Moroney and Ynalvez (2007) \\
\hline$\gamma$-CAG1 & Mitochondria & $\begin{array}{l}\text { Not available (possible for production of inorganic carbon } \\
\text { from } \mathrm{CO}_{2} \text { released during respiration in mitochondria) }\end{array}$ & $\begin{array}{l}\text { Cardol et al. (2005), } \\
\quad \text { Moroney et al. (2011) }\end{array}$ \\
\hline$\gamma$-CAG2 & Mitochondria & $\begin{array}{l}\text { Not available (possible for production of inorganic carbon } \\
\text { from } \mathrm{CO}_{2} \text { released during respiration in mitochondria) }\end{array}$ & $\begin{array}{l}\text { Cardol et al. (2005), } \\
\quad \text { Moroney et al. (2011) }\end{array}$ \\
\hline$\gamma$-CAG3 & Mitochondria & $\begin{array}{l}\text { Not available (possible for production of inorganic carbon } \\
\text { from } \mathrm{CO}_{2} \text { released during respiration in mitochondria) }\end{array}$ & $\begin{array}{l}\text { Cardol et al. (2005), } \\
\quad \text { Moroney et al. (2011) }\end{array}$ \\
\hline
\end{tabular}


in mitochondria by chloroplasts when the rate of ATP generation in photophosphorylation is lower than the rate of ATP utilization in RuBisCO, and (3) utilization and removal of cellular $\mathrm{O}_{2}$ during respiration in mitochondria thus enhance efficiency of photosynthesis as are result of decrease in possibility of photoreduction by PSI (Dang et al. 2014, Yang et al. 2015). While cultivating microalgae in open ponds or photobioreactor, part of the culture remains unexposed to light. If the adequate amount of organic carbon and nutrients are present, mixotrophic growth may dominant in these regions having no or limited light availability (Ji et al. 2014b, Perez-Garcia and Bashan 2015). However, sometimes it is difficult to differentiate the mixotrphic growth from the synergic growth of microalgae and the native bacteria of the wastewater system (Fig. 1). It is well reported that the microalgae and the bacteria in the wastewater grow in a synergic relationship through exchange of nutrients, $\mathrm{CO}_{2}$ and $\mathrm{O}_{2}$ (Rawat et al. 2011, Ramanan et al. 2016). Hence, apart from the mixotrophic growth, synergic growth also results in higher rate of nutrient / pollutant removal and biomass production during bioremediation.

\section{ENVIRONMENTAL REMEDIATION BY MICROAL- GAE}

\section{Bio-mitigation of $\mathrm{CO}_{2}$ using microalgae through autotrophic growth}

Control of increasing atmospheric concentration of $\mathrm{CO}_{2}$ is achievable by algal-induced $\mathrm{CO}_{2}$ fixation (Alpert et al. 1992). Researches in this area focused on strain selection, culture condition optimization, adaptive evolution, and mutation study (López et al. 2013). Microalgae are divided into (1) $\mathrm{CO}_{2}$ sensitive (intolerance) species inhibited by $<2-5 \% \mathrm{CO}_{2}$, (2) $\mathrm{CO}_{2}$ tolerant species that can cope with $5-20 \% \mathrm{CO}_{2}$, and (3) extreme $\mathrm{CO}_{2}$ tolerant species that tolerate $20-100 \% \mathrm{CO}_{2}$ (Solovchenko and Khozin-Goldberg 2013). High $\mathrm{CO}_{2}$ cause high ATP generation, shutdown of $\mathrm{CO}_{2}$-concentrating mechanisms, upregulation of $\mathrm{H}^{+}$-ATPases, alkalization of medium and adjustment of membranes' fatty acid composition (Solovchenko and Khozin-Goldberg 2013). During autotrophic and mixotrophic processing, increase in $\mathrm{CO}_{2}$ concentration in medium caused microalgae to accumulate lipid and polyunsaturated fatty acid (Tang et al. 2011) and stop organic substrate utilization (Sforza et al. 2012). Increase in light enhance microalgal $\mathrm{CO}_{2}$ sequestering in Chlorella vulgaris (Gonçalves et al. 2014), Alphanothece microscopica
(Jacob-Lopes et al. 2009), and Chlorella PY-ZU1 (Cheng et al. 2013a). All mutagenesis studies of microalgae reported increase in $\mathrm{CO}_{2}$ tolerance and fixation (Lee et al. 2002, Li et al. 2011, 2015, Kao et al. 2012b, Cheng et al. 2013b). Microalgae have shown promising potential for reduction of $\mathrm{CO}_{2}$ in flue gas (Borkenstein et al. 2011, Chiu et al. 2011, Li et al. 2011, Cheng et al. 2014, 2015) and for simultaneously production of neutral lipid. Culture system can be combined wastewater treatment and make use impure $\mathrm{CO}_{2}$ gas (Chinnasamy et al. 2010, Li et al. 2011). Several reports have highlighted the advantages (in terms of higher biomass yield and rate of pollutant removal) of coupled process of wastewater treatment with $\mathrm{CO}_{2}$ from waste gases including flue gas (Kumar et al. 2011, Van Den Hende et al. 2011, Prajapati et al. 2013a). Moreover, $\mathrm{CO}_{2}$ fraction of the biogas can also be used as carbon source for microalgal culturing at large scale (Kao et al. 2012a, Serejo et al. 2015).

\section{Phycoremediation of wastewater nutrients}

Introducing abundant nutrients into biochemical cycles through agricultural practices, urbanization, and industrialization resulted in nutrient-enrich-water-bodies and caused dissolved oxygen depletion and eutrophication. Wastewater treatment can be achieved when it is used for culturing of microalgae by utilizing the nutrients.

Removal of inorganic nutrients. Nitrogen and phosphorous are primary nutrients for algae and are transformed from one form to another. The wastewaters generated through various sources, particularly, livestock wastewater (Choudhary et al. 2016), agricultural runoff (Vymazal and Březinová 2015) and digested manure (Prajapati et al. 2014b), are usually rich in $\mathrm{N}$ and P. In the recent studies, removal of inorganic nutrient including $\mathrm{N}$ and $\mathrm{P}$, has been reported in the range of $80-100$ by use of pure and mixed algal cultures (Prajapati et al. 2013a, 2013b, Choudhary et al. 2016). Further, use of immobilized algae for removal of inorganic nutrients from wastewater is also a cost effective approach that it can replace the difficult process of microalgal biomass harvesting from the suspended culture (Mallick 2006). Many other microalgae species have equally been reported to treat wastewater from different sources and different operation modes (Table 2). The results showed that microalgae were able to reduce, with different efficiency, the total nitrogen, inorganic nitrogen compounds in wastewater and make the wastewater more suitable for safe discharge. 
Bioremediation of dissolved organic nitrogen. Dissolved organic nitrogen (DON) is another crucial $\mathrm{N}$ source for algal species (Gobler et al. 2002, Glibert et al. 2007) and its structural composition is source dependent. DON (include urea, amino acids, amino sugars, proteins, nucleic acids, fulvic acids, humic acids, and a variety of uncharacterized components) comprises a great proportion of total dissolve nitrogen in rivers, lakes, and marine ecosystem. The fraction of DON in surface waters is higher than other constituents in the $\mathrm{N}$ pools, such as particulate organic nitrogen, ammonium, nitrate, and nitrite (Berman and Bronk 2003). Initially, DON was believed to be unavailable for microalgae and microorganism. However, studies have shown otherwise (Caperon et al. 1979, Bronk et al. 1994, 2010) and the microalgae roles in DON removal directly or indirectly. Overall, DON from urban runoff, animal feedlot runoff, and other autochthonous production are readily bioavailable to bacteria and algae, unlike DON from forest, wetlands, agricultural runoff, lagoons, and wastewater treatment plant effluents (Seitzinger and Sanders 1997, 1999, Bronk et al. 2010). Previous investigations proved that at least $50-85 \%$ of the refractory portion of DON became biodegradable and / or bioavailable to living organisms in water ecosystems when the optimum environmental conditions are met (Koopmans and Bronk 2002, Pehliv-

Table 2. Literature review on bioremediation of pesticides, endocrine disruptors, and hydrocarbon using microalgae

\begin{tabular}{|c|c|c|}
\hline Pollutants & Microalgae & Reference \\
\hline \multicolumn{3}{|l|}{ Pesticides } \\
\hline Dimethomorph, pyrimethanil, isoproturon & Scenedesmus obliquus, Scenedesmus quadricauda & Dosnon-Olette et al. (2010) \\
\hline Fluroxypyr & Chlamydomonas reinhardtii & Zhang et al. (2011) \\
\hline Isoproturon & Chlamydomonas reinhardtii & Bi et al. (2012) \\
\hline Prometryne & Chlamydomonas reinhardtii & Jin et al. (2012) \\
\hline Fenhexamid, atrazine & Scenedesmu obliquus & Mofeed and Mosleh (2013) \\
\hline Atrazine & Chlamydomonas mexicana & Kabra et al. (2014) \\
\hline Mesotrione & Microcystis sp., Scenedesmus quadricauda & Ni et al. (2014) \\
\hline Acephate, imidacloprid & Chlamydomonas mexicana & Kumar et al. (2011) \\
\hline \multicolumn{3}{|l|}{ Endocrine disruptors } \\
\hline Nonylphenol, octylphenol & Scenedesmus obliquus & Zhou et al. (2013) \\
\hline$\beta$-Estradiol, $17 \alpha$-ethinylestradiol & Selenastrum capricornutum & Perron and Juneau (2011) \\
\hline$\beta$-Estradiol, $17 \alpha$-ethinylestradiol, bisphenol A & Chlamydomonas reinhardtii & Hom-Diaz et al. (2015) \\
\hline $17 \alpha$-estradiol, estrone, $17 \beta$-estradiol, estriol & Scenedesmus dimorphus & Zhang et al. (2014) \\
\hline Bisphenol A & Monoraphidium braunii & Gattullo et al. (2012) \\
\hline Biophenol A & Stephanodiscus hantzschii & Li et al. (2009) \\
\hline $\begin{array}{l}\text { 17 } \alpha \text {-ethinylestradiol, } 17 \beta \text {-estradiol, natural } \\
\text { hormones estrone }\end{array}$ & $\begin{array}{l}\text { Anabaena cylindrica, Chlorococcus, Spirulina plat } \\
\text { ensis, Chlorella, Scenedesmus quadricauda, and } \\
\text { Anaebena var. }\end{array}$ & Shi et al. (2010) \\
\hline $\begin{array}{l}\text { 4-(1,1,3,3-tetramethylbutyl) phenol, } \\
\text { technical-nonylphenol, 4-n-nonylphenol, } \\
\text { bisphenol A }\end{array}$ & $\begin{array}{l}\text { Algae mixture (mostly Chlorophyceae class and } \\
\text { cyanobacteria }\end{array}$ & Abargues et al. (2013) \\
\hline Bisphenol A & Chlorella fisca & Hirooka et al. (2003) \\
\hline Biophenol A & Chlamydomonas Mexicana, Chlorella vulgaris & Ji et al. $(2014 a)$ \\
\hline \multicolumn{3}{|l|}{ Hydrocarbons } \\
\hline Aliphatic and polycyclic aromatic & Prototheca zopfii & Ueno et al. (2006) \\
\hline Polycyclic aromatic & Prototheca zopfii & Ueno et al. (2007) \\
\hline n-Alkanes & Prototheca zopfii & Suzuki and Yamaya (2005) \\
\hline n-Alkanes and polycyclic aromatic & Scenedesmus obliquus, Nitzschia linearis & Gamila and Ibrahim (2004) \\
\hline Crude oil & 7 microalgae isolated from Nile River & Ibrahim and Gamila (2004) \\
\hline Phenanthrene and fluoranthene & Skeletonema costatum, Nitzschia sp. & $\begin{array}{l}\text { Hong et al. (2008), } \\
\quad \text { Tang et al. (2010) }\end{array}$ \\
\hline Light extractable petroleum hydrocarbons & $\begin{array}{l}\text { Algal-bacterial solution and algal solution prepared by } \\
\text { UV inhibition of bacterial growth }\end{array}$ & $\begin{array}{l}\text { Jacques and McMartin } \\
\text { (2009) }\end{array}$ \\
\hline Aliphatic and aromatic & $\begin{array}{l}\text { Microalgal-bacterial consortium containing } \\
\text { Scenedesmus obliquus }\end{array}$ & Tang et al. (2010) \\
\hline Phananthrene & $\begin{array}{l}\text { Microalgal-bacterial consortium containing Chlorella } \\
\text { sorokiniana and Pseudomonas migulae }\end{array}$ & Muñoz et al. (2003) \\
\hline
\end{tabular}


anoglu and Sedlak 2004, Urgun-Demirtas et al. 2008, Sattayatewa et al. 2009, Simsek et al. 2012). In addition, photochemical decomposition of DON can stimulate algal growth indirectly by releasing low molecular weight labile compounds, such as urea, amino acids, and ammonium (Bushaw-Newton and Moran 1999, Vähätalo and Zepp 2005, Vähätalo and Järvinen 2007).

There is no direct method available to measure DON, however, it can be determined from the mass-balance equation of nitrogen and the accuracy of measurement can be further improved by using pretreatment method which consequently minimized dissolve inorganic nitrogen and maximized DON level in the wastewater sample (Crumpton et al. 1992, Vandenbruwane et al. 2007, Sattayatewa et al. 2011). Bioavailable DON (ABDON) is the portion of DON which can be up taken by algae or algae + bacteria (Urgun-Demirtas et al. 2008, Sattayatewa et al. 2009, Simsek et al. 2012). ABDON evaluate the potential environmental effect of wastewater-derived DON to river and estuaries and provides a better understanding for the impact of DON in aquatic environment. Previous studies have mostly applied algae Selenastrum capricornutum to determine and removal of wastewater ABDON (Pehlivanoglu and Sedlak 2004, Urgun-Demirtas et al. 2008, Sattayatewa et al. 2009, Simsek et al. 2012). However, the role of native bacteria in removal of ABDON through the synergic growth with microalgae (Muñoz and Guieysse 2006, Alcántara et al. 2015) cannot be neglected.

For successful reduction of DON in wastewater, low molecular weight, light, and ability of microalgae to synthesis protease are crucial factors (Langheinrich 1995, Bronk et al. 2010). While DON has been widely studied in municipal wastewater, there are limited studies in animal wastewater. As of the authors' knowledge, data on ABDON in animal wastewaters is unavailable or very limited.

\section{Biodegradation of cyanide compounds}

Cyanides are toxic compounds containing carbonnitrogen radicals $\left(\mathrm{CN}^{-}\right)$(e.g., hydrogen cyanide, sodium cyanide, potassium cyanide, and thiocyanates) and originate from manufacturing companies such as metal finishing, gold ore processing, plastic manufacturing, food processing, and steel production (Knowles and Bunch 1986, Gould et al. 2012). Biological methods, including use of microalgae, for removal of tightly bonded cyanide compounds from wastewater is cost effective and more efficient compared to chemical and physical counterparts (Gurbuz et al. 2009). Ability to withstand and / or utilize cyanide in wastewater varies among different al- gae species. Although growth of microalgae could be initially retarded by cyanide, some microalgae species acclimatized quickly. Algae is capable of withstanding higher (up to $400 \mathrm{mg} \mathrm{L}^{-1}$ ) cyanide concentration (Gurbuz et al. 2002), an advantage over bacteria since bacteria that can only withstand maximum of $300 \mathrm{mg} \mathrm{L}^{-1}$ (Adams et al. 2001). Currently, there is no report on molecular study of metabolism of cyanide in microalgae. Presumably, similar to other microorganisms, microalgae utilized cyanide through series of enzymatic reactions for bioconversion into simple organic or inorganic molecules. Vanelslander et al. (2011) reported production of a diverse mixture of iodinated and brominated metabolites including bromine cyanide and iodine cyanide by diatom Nitzschia cf pellucida. Numerous enzymes that are responsible for metabolism of cyanide compounds have been identified in plants, fungi, and bacteria. Hydrolytic pathway involves cyanide hydratase, nitrile hydratase, thiocyanate hydrolase, nitrilase, and cyanidase; oxidative pathway involves cyanide monooxygenase, cyanide cyanase, and cyanide dioxygenase; reductive pathway involves enzyme nitrogenase; substitution / transfer pathway involves mercaptopyruvate sulfurtransferase and rhodanese while syntheses pathway involves $\beta$-cyanoalanine synthase, and $\gamma$-cyano- $\alpha$-aminobutyric acid synthase (Gupta et al. 2010, Gould et al. 2012). However, none of the aforementioned enzymes have been reportedly present in microalgae. Besides, microalgae have been shown to metabolize cyanide from wastewater. Microalgae assimilated cyanides compounds as source of carbon or nitrogen (Gupta et al. 2010). Additional work is needed to investigate the cyanide metabolic pathway in microalgae.

\section{Bioremediation of pesticides}

Utilization of pesticides is common agricultural practice to increase food production, but when overused, pesticides become harmful to soil, aquatic ecosystem, and human health (Zhang et al. 2011). Similarly, residue of pesticides on plant materials, soils, water bodies found their ways in to animals and human systems (Kannan et al. 1999). Microalgal treatment of water bodies has been identified as a very suitable approach for bioremediation of pesticides (Table 2).

Fresh water microalgae have exhibited different efficiencies for pesticides removal from wastewater (Dosnon-Olette et al. 2010). Fluorxypyr and isoproturon were rapidly accumulated into the microalgae $C$. reinhardtii cell matrix (Zhang et al. 2011). Studies have equally shown possibility of microalgae to biodegrade some pes- 
ticides. Microalgae exhibited different level of toxicological effects with respect to different pesticides. Most of the reports showed induction of oxidative responses by the microalgae in the presence of high concentration of pesticides. In addition, cell morphology was altered and cell photosynthetic apparatus were disrupted. The following toxicology reactions: decrease in soluble protein and total antioxidant content, increase in superoxide dismutase and peroxidase activity, reduction of transcription of photosynthetic genes and one energy gene and cellular structural damage (Shen et al. 2014). Esperanza et al. (2015) showed that C. reinhardtii, subjected to sublethal concentration of atrazine for 3 and $24 \mathrm{~h}$, experienced changed in gene implicated in amino acid catabolism and respiratory cellular process. It was suggested that, photosynthesis was inhibited and the cell was forced to seek heterotrophic metabolism in order to survive. Ability to withstand certain concentration of specific pesticides varies among different species of microalgae. Microalgae are not only capable of bioaccumulation of pesticides, they can also biodegrade them when pesticides are presented in sublethal concentration. However, microalgal metabolic pathway for bioremediation of pesticides is still an area to be explored in future researches.

\section{Bioremediation of endocrine disruptors}

Endocrine disruptors are a group of compounds with estrogenic activities. They have been found in wastewaters, and also impacted several health issues in living organisms (Hom-Diaz et al. 2015). Endocrine disruptors causes morphological alterations, fertility reduction, interference in sex differentiation, enhancing growth of MCF-7 human breast cancer cell and mutagenic action on RSa human cells (Gattullo et al. 2012). Many studies on bioremediation of wastewater containing endocrine disruptors using microalgae have been conducted (Nadal et al. 2006, Della Greca et al. 2008, Li et al. 2009, Shi et al. 2010, Gattullo et al. 2012, Zhou et al. 2013, Hom-Diaz et al. 2015). Microalgae can tolerated high concentration of endocrine disruptors, therefore, they are suitable for bioremediation of endocrine disruptors (Perron and Juneau 2011). Abargues et al. (2013) showed that aerated system was more efficient for removal of micropollutants while unaerated system was only suitable for removal of 4-nnonylphenol. In another study, Chlorella fisca was able to remove most of bisphenol A in presence of light. Almost all the bisphenol A was removed under continuous light, about $82 \%$ of bisphenol removed under light : dark ( $8: 16)$ condition while $42 \%$ of bisphenol A was removed under dark condition (Hirooka et al. 2005).

The possible processes for bioremediation of endocrine disruptors in water are sorption, biodegradation, and photolytic degradation (Shi et al. 2010). Rate of bioremediation of endocrine disruptors, in algae system, varies among different algae species and inversely proportional to molecular weight of the endocrine disruptors (Ji et al. 2014a, Hom-Diaz et al. 2015). More studies on strain selection is required in order to identify microalgae with high bioremediation properties against endocrine disruptors. Likewise, other conditions (temperature, treatment time, presence of light and concentration, and type of endocrine disruptors) that affect bioremediation of endocrine disruptors need attention in future researches.

\section{Bioremmediation of hydrocarbons}

Bioremmediation has been identified as most suitable method to combat hydrocarbon contamination of soil and water as a result of industrial discharges (Subashchandrabose et al. 2013). Microalgae, as a member of microbial community, plays significant role toward bioremediation of toxic compounds including hydrocarbon. Microalgae has shown ability to produce enzymes capable of degrading hydrocarbon (Chekroun et al. 2014). Earlier studies on microalgal remediation of hydrocarbon polluted environment have proven that several species of microalgae are capable of utilizing hydrocarbons as carbon source (Semple et al. 1999). The most popular hydrocarbon degrading microalgae is Prototheca zopfii and has been investigated in cell free and immobilized systems (Suzuki and Yamaya 2005, Ueno et al. 2006, 2007, deBashan and Bashan 2010). Immobilization of microalgae reduced lag growth phase associated with biodegradation of n-alkanes. The immobilized thermotolerant strain selectively degraded aliphatic hydrocarbon in the mixed hydrocarbon substrate unlike the nonthermotolerant strain (Ueno et al. 2006). Microalgae have different affinity for degradation of n-alkanes and polycyclic aromatic hydrocarbons (Gamila and Ibrahim 2004). Scenedesmus obliquus showed greater affinity toward degradation of polycyclic hydrocarbons than n-alkanes, unlike Nitzschia linearis that exhibited higher preference for degradation of n-alkanes than polycyclic hydrocarbons. Also, seven microalgae isolated from Nile river exhibited different potentials when tested for bioremediation of crude oil (Ibrahim and Gamila 2004). Tang et al. (2010) and Hong et al. (2008) showed that degradation and accumulation abilities of Nitzschia sp. were higher than those of Skeletonema costatum and that it is easier to degrade fluoran- 
thene compared to phenanthrene.

Microalgae has been reported to play important role, but not directly responsible, in microbial consortia for degradation of light extractable petroleum hydrocarbons in petroleum-contaminated water (Jacques and McMartin 2009). It is possible that produced oxygen by microalgae during photosynthesis process is easily utilized by bacteria (Muñoz and Guieysse 2006). Several microalgalbacterial consortia have also been studied for bioremediation of hydrocarbons. Microalgal-bacterial consortium containing S. obliquus showed high degradation efficiency against aliphatic and aromatic hydrocarbons of crude oil (Tang et al. 2010). Another report showed that microalgal-bacterial consortium (Chlorella sorokiniana and Pseudomonas migulae) biodegraded between 200 to $500 \mathrm{mg} \mathrm{L}^{-1}$ of phananthrene under photosynthetic conditions without external supply of oxygen (Muñoz et al. 2003). Additional studies are needed to explore metabolic pathway that is responsible for bioaccumulation and biodegration of hydrocarbon in microalgae and microalgalbacterial consortia.

\section{FACTORS AFFECTING MICROALGAL GROWTH AND PHYCOREMEDIATION}

Growth and the nutrient removal potential of microalgae is greatly affected by the process condition (such as temperature and $\mathrm{pH}$ ), type and composition of wastewater used and availability of light and $\mathrm{CO}_{2}$ (Pittman et al. 2011, Prajapati et al. 2013a). For instance, most of the microalgae can efficiently grow under ambient conditions with temperature up to $40^{\circ} \mathrm{C}$ while some are very sensitive and can grow only if the temperature is below $25^{\circ} \mathrm{C}$ (Converti et al. 2009). On the other hand, extremophiles can withstand the lower temperature range and can grow in sea ice (Thomas and Dieckmann 2002). However, in practice, the wastewater treatment is usually carried out in the mesophilic temperature range, which is suitable for most of the common microalgae.

The availability of the nutrient and micronutrient in the wastewater is of major concern for effective phycoremediation. Domestic wastewater contains ample amount of nutrient to support microalgal growth. However, the presence of antimicrobial compounds (originated from daily use products such as soaps, toothpaste, and other products) in the wastewater may have negative effect on microalgal growth (Rawat et al. 2011, Iatrou et al. 2014, Prajapati et al. 2014a). Similarly, presence (above the inhibitory level) of heavy metals and other toxic compound in the industrial effluents are harmful for microalgae and may result in the failure of entire wastewater treatment systems (Chekroun and Baghour 2013, Mishra 2014). Moreover, though microalgae have been reported to have active role in degradation of pesticides and cyanide compounds, the concentration above tolerance levels become lethal to most of the microalgae. However, immobilized microalgae can be used to overcome the inhibition due to presence of heavy metals (Mallick 2002). Hence, it is obvious that special care shall be given for selection of particular microalgal strain for given wastewater remediation. Moreover, there is urgent need of developing methodology for determination and removal of antimicrobial and toxic compound prior to microalgal growth in the wastewater.

\section{CONCLUSION}

Microalgal growth regimes and bioremediation of $\mathrm{CO}_{2}$, nutrients, cyanide, pesticides, endocrine disruptors, and hydrocarbons have been well reviewed and acknowledged. A number of methods have been developed to remove wastes and toxic contaminants; however, microalgal remediation is a promising and cost effective way to remove pollutants. Microalgae are an abundantly present biological agent in the nature and have been identified as one of the most viable and feasible environmental control methods. They are taxonomically diverse and contain multiple metabolic pathways for different growth regimes. Strain selection has been widely investigated, little attentions has been drawn to microalgae that are extremophiles. Additionally, engineering of metabolic pathways using biotechnology techniques is a promising research opportunity and shall form the body of future researches. This technique should be applied efficiently towards utilization of microalgae to rid wastewater from DON. Hence, understanding the growth regimes of microalgae help to optimize environmental remediation and metabolites production.

\section{REFERENCES}

Abargues, M. R., Ferrer, J., Bouzas, A. \& Seco, A. 2013. Removal and fate of endocrine disruptors chemicals under lab-scale postreatment stage: removal assessment using light, oxygen and microalgae. Bioresour. Technol. 149:142-148.

Adams, D. J., Komen, J. V. \& Pickett, T. M. 2001. Biological 
cyanide degradation. In Young, C. (Ed.) Cyanide: Social, Industrial and Economic Aspects. The Metals Society, Warrendale, PA, pp. 203-213.

Alcántara, C., Fernández, C., García-Encina, P. A. \& Muñoz, R. 2015. Mixotrophic metabolism of Chlorella sorokiniana and algal-bacterial consortia under extended dark-light periods and nutrient starvation. Appl. Microbiol. Biotechnol. 99:2393-2404.

Alpert, S. B., Spencer, D. F. \& Hidy, G. 1992. Biospheric options for mitigating atmospheric carbon dioxide levels. Energy Convers. Manag. 33:729-736.

Baba, M. \& Shiraiwa, Y. 2012. High- $\mathrm{CO}_{2}$ response mechanisms in microalgae. In Najafpour, M. (Ed.) Advances in Photosynthesis: Fundamental Aspects. InTech, Rijeka, pp. 299-320.

Bell, G. 2013. Experimental evolution of heterotrophy in a green alga. Evolution 67:468-476.

Berman, T. \& Bronk, D. A. 2003. Dissolved organic nitrogen: a dynamic participant in aquatic ecosystems. Aquat. Microb. Ecol. 31:279-305.

Bhatnagar, A., Chinnasamy, S., Singh, M. \& Das, K. C. 2011. Renewable biomass production by mixotrophic algae in the presence of various carbon sources and wastewaters. Appl. Energy 88:3425-3431.

Bi, Y. F., Miao, S. S., Lu, Y. C., Qiu, C. B., Zhou, Y. \& Yang, H. 2012. Phytotoxicity, bioaccumulation and degradation of isoproturon in green algae. J. Hazard. Mater. 243:242249.

Borkenstein, C. G., Knoblechner, J., Frühwirth, H. \& Schagerl, M. 2011. Cultivation of Chlorella emersonii with flue gas derived from a cement plant. J. Appl. Phycol. 23:131-135.

Bronk, D. A., Glibert, P. M. \& Ward, B. B. 1994. Nitrogen uptake, dissolved organic nitrogen release, and new production. Science 265:1843-1846.

Bronk, D. A., Roberts, Q. N., Sanderson, M. P., Canuel, E. A., Hatcher, P. G., Mesfioui, R., Filippino, K. C., Mulholland, M. R. \& Love, N. G. 2010. Effluent organic nitrogen (EON): bioavailability and photochemical and salinitymediated release. Environ. Sci. Technol. 44:5830-5835.

Bushaw-Newton, K. L. \& Moran, M. A. 1999. Photochemical formation of biologically available nitrogen from dissolved humic substances in coastal marine systems. Aquat. Microb. Ecol. 18:285-292.

Cannons, A. C. \& Pendleton, L. C. 1994. Possible role for mRNA stability in the ammonium-controlled regulation of nitrate reductase expression. Biochem. J. 297:561-565.

Caperon, J., Schell, D., Hirota, J. \& Laws, E. 1979. Ammonium excretion rates in Kaneohe Bay, Hawaii, measured by a ${ }^{15} \mathrm{~N}$ isotope dilution technique. Mar. Biol. 54:33-40.

Cardol, P., González-Halphen, D., Reyes-Prieto, A., Baurain,
D., Matagne, R. F. \& Remacle, C. 2005. The mitochondrial oxidative phosphorylation proteome of Chlamydomonas reinhardtii deduced from the Genome Sequencing Project. Plant Physiol. 137:447-459.

Cerón-García, M. C., Fernández-Sevilla, J. M., SánchezMirón, A., García-Camacho, F., Contreras-Gómez, A. \& Molina-Grima, E. 2013. Mixotrophic growth of Phaeodactylum tricornutum on fructose and glycerol in fedbatch and semi-continuous modes. Bioresour. Technol. 147:569-576.

Cheirsilp, B. \& Torpee, S. 2012. Enhanced growth and lipid production of microalgae under mixotrophic culture condition: effect of light intensity, glucose concentration and fed-batch cultivation. Bioresour. Technol. 110:510-516.

Chekroun, K. B. \& Baghour, M. 2013. The role of algae in phytoremediation of heavy metals: a review. J. Mater. Environ. Sci. 4:873-880.

Chekroun, K. B., Sánchez, E. \& Baghour, M. 2014. The role of algae in bioremediation of organic pollutants. Int. Res. J. Public Environ. Health 1:19-32.

Chen, G. -Q. \& Chen, F. 2006. Growing phototrophic cells without light. Biotechnol. Lett. 28:607-616.

Cheng, J., Huang, Y., Feng, J., Sun, J., Zhou, J. \& Cen, K. $2013 a$. Improving $\mathrm{CO}_{2}$ fixation efficiency by optimizing Chlorella PY-ZU1 culture conditions in sequential bioreactors. Bioresour. Technol. 144:321-327.

Cheng, J., Huang, Y., Feng, J., Sun, J., Zhou, J. \& Cen, K. $2013 b$. Mutate Chlorella sp. by nuclear irradiation to fix high concentrations of $\mathrm{CO}_{2}$. Bioresour. Technol. 136:496-501.

Cheng, J., Huang, Y., Lu, H., Huang, R., Zhou, J. \& Cen, K. 2014. The oxidation product $\left(\mathrm{NO}_{3}^{-}\right)$of $\mathrm{NO}$ pollutant in flue gas used as a nitrogen source to improve microalgal biomass production and $\mathrm{CO}_{2}$ fixation. RSC Adv. 4:4214742154.

Cheng, J., Yang, Z., Huang, Y., Huang, L., Hu, L., Xu, D., Zhou, J. \& Cen, K. 2015. Improving growth rate of microalgae in a $1191 \mathrm{~m}^{2}$ raceway pond to fix $\mathrm{CO}_{2}$ from flue gas in a coal-fired power plant. Bioresour. Technol. 190:235-241.

Chinnasamy, S., Bhatnagar, A., Hunt, R. W. \& Das, K. C. 2010. Microalgae cultivation in a wastewater dominated by carpet mill effluents for biofuel applications. Bioresour. Technol. 101:3097-3105.

Chiu, S. -Y., Kao, C. -Y., Huang, T. -T., Lin, C. -J., Ong, S. -C., Chen, C. -D., Chang, J. -S. \& Lin, C. -S. 2011. Microalgal biomass production and on-site bioremediation of carbon dioxide, nitrogen oxide and sulfur dioxide from flue gas using Chlorella sp. cultures. Bioresour. Technol. 102:9135-9142.

Choudhary, P., Bhattacharya, A., Prajapati, S. K., Kaushik, P. 
\& Malik, A. 2015. Phycoremediation-coupled biomethanation of microalgal biomass. In Kim, S. -K. (Ed.) Handbook of Marine Microalgae, Biotechnology Advances. Elsevier, Amsterdam, pp. 483-489.

Choudhary, P., Prajapati, S. K. \& Malik, A. 2016. Screening native microalgal consortia for biomass production and nutrient removal from rural wastewaters for bioenergy applications. Ecol. Eng. 91:221-230.

Converti, A., Casazza, A. A., Ortiz, E. Y., Perego, P. \& Del Borghi, M. 2009. Effect of temperature and nitrogen concentration on the growth and lipid content of Nannochloropsis oculata and Chlorella vulgaris for biodiesel production. Chem. Eng. Process. Process Intensif. 48:1146-1151.

Crumpton, W. G., Isenhart, T. M. \& Mitchell, P. D. 1992. Nitrate and organic $\mathrm{N}$ analyses with second-derivative spectroscopy. Limnol. Oceanogr. 37:907-913.

Dang, K. -V., Plet, J., Tolleter, D., Jokel, M., Cuiné, S., Carrier, P., Auroy, P., Richaud, P., Johnson, X., Alric, J., Allahverdiyeva, Y. \& Peltier, G. 2014. Combined increases in mitochondrial cooperation and oxygen photoreduction compensate for deficiency in cyclic electron flow in Chlamydomonas reinhardtii. Plant Cell 26:3036-3050.

Das, P., Lei, W., Aziz, S. S. \& Obbard, J. P. 2011. Enhanced algae growth in both phototrophic and mixotrophic culture under blue light. Bioresour. Technol. 102:3883-3887.

de-Bashan, L. E. \& Bashan, Y. 2010. Immobilized microalgae for removing pollutants: review of practical aspects. Bioresour. Technol. 101:1611-1627.

Della Greca, M., Pinto, G., Pistillo, P., Pollio, A., Previtera, L. \& Temussi, F. 2008. Biotransformation of ethinylestradiol by microalgae. Chemosphere 70:2047-2053.

Devriese, M., Tsakaloudi, V., Garbayo, I., León, R., Vílchez, C. \& Vigara, J. 2001. Effect of heavy metals on nitrate assimilation in the eukaryotic microalga Chlamydomonas reinhardtii. Plant Physiol. Biochem. 39:443-448.

Dosnon-Olette, R., Trotel-Aziz, P., Couderchet, M. \& Eullaffroy, P. 2010. Fungicides and herbicide removal in Scenedesmus cell suspensions. Chemosphere 79:117123.

Eriksson, M., Villand, P., Gardeström, P. \& Samuelsson, G. 1998. Induction and regulation of expression of a low$\mathrm{CO}_{2}$-induced mitochondrial carbonic anhydrase in Chlamydomonas reinhardtii. Plant Physiol. 116:637-641.

Esperanza, M., Seoane, M., Rioboo, C., Herrero, C. \& Cid, Á. 2015. Chlamydomonas reinhardtii cells adjust the metabolism to maintain viability in response to atrazine stress. Aquat. Toxicol. 165:64-72.

Fernández Sevilla, J. M., Cerón García, M. C., Sánchez Mirón, A., Belarbi, E. H., García Camacho, F. \& Molina Grima, E. 2004. Pilot-plant-scale outdoor mixotrophic cultures of Phaeodactylum tricornutum using glycerol in vertical bubble column and airlift photobioreactors: studies in fed-batch mode. Biotechnol. Prog. 20:728-736.

Ferrer-i-Carbonell, A. \& Gowdy, J. M. 2007. Environmental degradation and happiness. Ecol. Econ. 60:509-516.

Gamila, H. A. \& Ibrahim, M. B. M. 2004. Algal bioassay for evaluating the role of algae in bioremediation of crude oil: I-isolated strains. Bull. Environ. Contam. Toxicol. 73:883-889.

Gattullo, C. E., Bährs, H., Steinberg, C. E. W. \& Loffredo, E. 2012. Removal of bisphenol A by the freshwater green alga Monoraphidium braunii and the role of natural organic matter. Sci. Total Environ. 416:501-506.

Giordano, M., Beardall, J. \& Raven, J. A. 2005. $\mathrm{CO}_{2}$ concentrating mechanisms in algae: mechanisms, environmental modulation, and evolution. Annu. Rev. Plant Biol. 56:99131.

Glibert, P. M., Wazniak, C. E., Hall, M. R. \& Sturgis, B. 2007. Seasonal and interannual trends in nitrogen and brown tide in Maryland's coastal bays. Ecol. Appl. 17(Suppl. 5):S79-S87.

Gobler, C. J., Renaghan, M. J. \& Buck, N. J. 2002. Impacts of nutrients and grazing mortality on the abundance of Aureococcus anophagefferens during a New York brown tide bloom. Limnol. Oceanogr. 47:129-141.

Gonçalves, A. L., Simões, M. \& Pires, J. C. M. 2014. The effect of light supply on microalgal growth, $\mathrm{CO}_{2}$ uptake and nutrient removal from wastewater. Energy Convers. Manag. 85:530-536.

Gould, W. D., King, M., Mohapatra, B. R., Cameron, R. A., Kapoor, A. \& Koren, D. W. 2012. A critical review on destruction of thiocyanate in mining effluents. Miner. Eng. 34:38-47.

Gupta, N., Balomajumder, C. \& Agarwal, V. K. 2010. Enzymatic mechanism and biochemistry for cyanide degradation: a review. J. Hazard. Mater. 176:1-13.

Gurbuz, F., Ciftci, H. \& Akcil, A. 2009. Biodegradation of cyanide containing effluents by Scenedesmus obliquus. J. Hazard. Mater. 162:74-79.

Gurbuz, F., Karahan, A., Akcil, A. \& Ciftci, H. 2002. Degradation of cyanide by natural algae species. In Extended Abstracts of the Third International Congress 'Environmental, Micropaleontology, Microbiology and Metobentholog'(EMMM'2002), Vienna, pp. 1-6.

Hirooka, T., Akiyama, Y., Tsuji, N., Nakamura, T., Nagase, H., Hirata, K. \& Miyamoto, K. 2003. Removal of hazardous phenols by microalgae under photoautotrophic conditions. J. Biosci. Bioeng. 95:200-203.

Hirooka, T., Nagase, H., Uchida, K., Hiroshige, Y., Ehara, Y., Nishikawa, J., Nishihara, T., Miyamoto, K. \& Hirata, Z. 
2005. Biodegradation of bisphenol A and disappearance of its estrogenic activity by the green alga Chlorella fusca var. vacuolata. Environ. Toxicol. Chem. 24:1896-1901.

Hom-Diaz, A., Llorca, M., Rodríguez-Mozaz, S., Vicent, T., Barceló, D. \& Blánquez, P. 2015. Microalgae cultivation on wastewater digestate: $\beta$-estradiol and $17 \alpha$-ethynylestradiol degradation and transformation products identification. J. Environ. Manag. 155:106-113.

Hong, S. -J. \& Lee, C. -G. 2007. Evaluation of central metabolism based on a genomic database of Synechocystis PCC6803. Biotechnol. Bioprocess Eng. 12:165-173.

Hong, Y. -W., Yuan, D. -X., Lin, Q. -M. \& Yang, T. -L. 2008. Accumulation and biodegradation of phenanthrene and fluoranthene by the algae enriched from a mangrove aquatic ecosystem. Mar. Pollut. Bull. 56:1400-1405.

Iatrou, E. I., Stasinakis, A. S. \& Thomaidis, N. S. 2014. Consumption-based approach for predicting environmental risk in Greece due to the presence of antimicrobials in domestic wastewater. Environ. Sci. Pollut. Res. 21:12941-12950.

Ibrahim, M. B. M. \& Gamila, H. A. 2004. Algal bioassay for evaluating the role of algae in bioremediation of crude oil: II. freshwater phytoplankton assemblages. Bull. Environ. Contam. Toxicol. 73:971-978.

Im, C. -S., Zhang, Z., Shrager, J., Chang, C. -W. \& Grossman, A. R. 2003. Analysis of light and $\mathrm{CO}_{2}$ regulation in Chlamydomonas reinhardtii using genome-wide approaches. Photosynth. Res. 75:111-125.

Jacob-Lopes, E., Scoparo, C. H. G., Lacerda, L. M. C. F. \& Franco, T. T. 2009. Effect of light cycles (night/day) on $\mathrm{CO}_{2}$ fixation and biomass production by microalgae in photobioreactors. Chem. Eng. Process. Process Intensif. 48:306-310.

Jacques, N. R. \& McMartin, D. W. 2009. Evaluation of algal phytoremediation of light extractable petroleum hydrocarbons in subarctic climates. Remediat. J. 20:119-132.

Ji, M. -K., Kabra, A. N., Choi, J., Hwang, J. -H., Kim, J. R., Abou-Shanab, R. A. I., Oh, Y. -K. \& Jeon, B. -H. $2014 a$. Biodegradation of bisphenol A by the freshwater microalgae Chlamydomonas mexicana and Chlorella vulgaris. Ecol. Eng. 73:260-269.

Ji, Y., Hu, W., Li, X., Ma, G., Song, M. \& Pei, H. 2014b. Mixotrophic growth and biochemical analysis of Chlorella vulgaris cultivated with diluted monosodium glutamate wastewater. Bioresour. Technol. 152:471-476.

Jin, Z. P., Luo, K., Zhang, S., Zheng, Q. \& Yang, H. 2012. Bioaccumulation and catabolism of prometryne in green algae. Chemosphere 87:278-284.

Kabra, A. N., Ji, M. -K., Choi, J., Kim, J. R., Govindwar, S. P. \& Jeon, B. -H. 2014. Toxicity of atrazine and its bioac- cumulation and biodegradation in a green microalga, Chlamydomonas mexicana. Environ. Sci. Pollut. Res. Int. 21:12270-12278.

Kannan, K., Senthilkumar, K. \& Giesy, J. P. 1999. Occurrence of butyltin compounds in human blood. Environ. Sci. Technol. 33:1776-1779.

Kao, C. -Y., Chiu, S. -Y., Huang, T. -T., Dai, L., Hsu, L. -K. \& Lin, C. -S. 2012a. Ability of a mutant strain of the microalga Chlorella sp. to capture carbon dioxide for biogas upgrading. Appl. Energy 93:176-183.

Kao, C. -Y., Chiu, S. -Y., Huang, T. -T., Dai, L., Wang, G. -H., Tseng, C. -P., Chen, C. -H. \& Lin, C. -S. 2012b. A mutant strain of microalga Chlorella sp. for the carbon dioxide capture from biogas. Biomass Bioenergy 36:132-140.

Kaushik, P. \& Malik, A. 2015. Mycoremediation of synthetic dyes: an insight into the mechanism, process optimization and reactor design. In Singh, S. N. (Ed.) Microbial Degradation of Synthetic Dyes in Wastewaters. Springer, Cham, pp. 1-25.

Knowles, C. J. \& Bunch, A. W. 1986. Microbial cyanide metabolism. Adv. Microb. Physiol. 27:73-111.

Koopmans, D. J. \& Bronk, D. A. 2002. Photochemical production of dissolved inorganic nitrogen and primary amines from dissolved organic nitrogen in waters of two estuaries and adjacent surficial groundwaters. Aquat. Microb. Ecol. 26:295-304.

Kruse, O., Rupprecht, J., Mussgnug, J. H., Dismukes, G. C. \& Hankamer, B. 2005. Photosynthesis: a blueprint for solar energy capture and biohydrogen production technologies. Photochem. Photobiol. Sci. 4:957-970.

Kumar, K., Dasgupta, C. N., Nayak, B., Lindblad, P. \& Das, D. 2011. Development of suitable photobioreactors for $\mathrm{CO}_{2}$ sequestration addressing global warming using green algae and cyanobacteria. Bioresour. Technol. 102:49454953.

Langheinrich, U. 1995. Plasma membrane-associated aminopeptidase activities in Chlamydomonas reinhardtii and their biochemical characterization. Biochim. Biophys. Acta 1249:45-57.

Lee, J. W., Mets, L. \& Greenbaum, E. 2002. Improvement of photosynthetic $\mathrm{CO}_{2}$ fixation at high light intensity through reduction of chlorophyll antenna size. Appl. Biochem. Biotechnol. 98-100:37-48.

Li, D., Wang, L., Zhao, Q., Wei, W. \& Sun, Y. 2015. Improving high carbon dioxide tolerance and carbon dioxide fixation capability of Chlorella sp. by adaptive laboratory evolution. Bioresour. Technol. 185:269-275.

Li, F. -F., Yang, Z. -H., Zeng, R., Yang, G., Chang, X., Yan, J. -B. \& Hou, Y. -L. 2011. Microalgae capture of $\mathrm{CO}_{2}$ from actual flue gas discharged from a combustion chamber. Ind. 
Eng. Chem. Res. 50:6496-6502.

Li, R., Chen, G. -Z., Tam, N. F. Y., Luan, T. -G., Shin, P. K. S., Cheung, S. G. \& Liu, Y. 2009. Toxicity of bisphenol A and its bioaccumulation and removal by a marine microalga Stephanodiscus hantzschii. Ecotoxicol. Environ. Saf. 72:321-328.

Liang, Y., Sarkany, N. \& Cui, Y. 2009. Biomass and lipid productivities of Chlorella vulgaris under autotrophic, heterotrophic and mixotrophic growth conditions. Biotechnol. Lett. 31:1043-1049.

López, J. C., Quijano, G., Souza, T. S. O., Estrada, J. M., Lebrero, R. \& Muñoz, R. 2013. Biotechnologies for greenhouse gases $\left(\mathrm{CH}_{4}, \mathrm{~N}_{2} \mathrm{O}\right.$, and $\left.\mathrm{CO}_{2}\right)$ abatement: state of the art and challenges. Appl. Microbiol. Biotechnol. 97:22772303.

Mallick, N. 2002. Biotechnological potential of immobilized algae for wastewater $\mathrm{N}, \mathrm{P}$ and metal removal: a review. Biometals 15:377-390.

Mallick, N. 2006. Immobilization of microalgae. In Guisan, J. M. (Ed.) Immobilization of Enzymes and Cells. Humana Press, Totowa, NJ, pp. 373-391.

Mandal, A. K., Sarma, P. M., Singh, B., Jeyaseelan, C. P., Channashettar, V. A., Lal, B. \& Datta, J. 2012. Bioremediation: an environment friendly sustainable biotechnological solution for remediation of petroleum hydrocarbon contaminated waste. ARPN J. Sci. Technol. 2:1-12.

Miazek, K., Remacle, C., Richel, A. \& Goffin, D. 2014. Effect of lignocellulose related compounds on microalgae growth and product biosynthesis: a review. Energies 7:4446-4481.

Mishra, A. \& Malik, A. 2013. Recent advances in microbial metal bioaccumulation. Crit. Rev. Environ. Sci. Technol. 43:1162-1222.

Mishra, V. 2014. Biosorption of zinc ion: a deep comprehension. Appl. Water Sci. 4:311-332.

Mitra, M., Lato, S. M., Ynalvez, R. A., Xiao, Y. \& Moroney, J. V. 2004. Identification of a new chloroplast carbonic anhydrase in Chlamydomonas reinhardtii. Plant physiol. 135:173-182.

Mofeed, J. \& Mosleh, Y. Y. 2013. Toxic responses and antioxidative enzymes activity of Scenedesmus obliquus exposed to fenhexamid and atrazine, alone and in mixture. Ecotoxicol. Environ. Saf. 95:234-240.

Morales-Sánchez, D., Martinez-Rodriguez, O. A., Kyndt, J. \& Martinez, A. 2015. Heterotrophic growth of microalgae: metabolic aspects. World J. Microbiol. Biotechnol. 31:19.

Morales-Sánchez, D., Tinoco-Valencia, R., Kyndt, J. \& Martinez, A. 2013. Heterotrophic growth of Neochloris oleoabundans using glucose as a carbon source. Biotechnol.
Biofuels 6:100.

Moroney, J. V., Ma, Y., Frey, W. D., Fusilier, K. A., Pham, T. T., Simms, T. A., DiMario, R. J., Yang, J. \& Mukherjee, B. 2011. The carbonic anhydrase isoforms of Chlamydomonas reinhardtii: intracellular location, expression, and physiological roles. Photosynth. Res. 109:133-149.

Moroney, J. V. \& Ynalvez, R. A. 2007. Proposed carbon dioxide concentrating mechanism in Chlamydomonas reinhardtii. Eukaryot. Cell 6:1251-1259.

Morris, I. 1974. Nitrogen assimilation and protein synthesis. In Stewart, W. D. P. (Ed.) Algal Physiology and Biochemistry. Blackwell, Oxford, pp. 583-609.

Muñoz, R. \& Guieysse, B. 2006. Algal-bacterial processes for the treatment of hazardous contaminants: a review. Water Res. 40:2799-2815.

Muñoz, R., Guieysse, B. \& Mattiasson, B. 2003. Phenanthrene biodegradation by an algal-bacterial consortium in twophase partitioning bioreactors. Appl. Microbiol. Biotechnol. 61:261-267.

Nadal, M., Wargent, J. J., Jones, K. C., Paul, N. D., Schuhmacher, M. \& Domingo, J. L. 2006. Influence of UV-B radiation and temperature on photodegradation of PAHs: preliminary results. J. Atmos. Chem. 55:241-252.

Nelson, D. L., Lehninger, A. L. \& Cox, M. M. 2008. Lehninger principles of biochemistry. Macmillan, New York, 1100 pp.

Ni, Y., Lai, J., Wan, J. \& Chen, L. 2014. Photosynthetic responses and accumulation of mesotrione in two freshwater algae. Environ. Sci. Processes Impacts 16:2288-2294.

Ogbonna, J., Ichige, E. \& Tanaka, H. 2002. Interactions between photoautotrophic and heterotrophic metabolism in photoheterotrophic cultures of Euglena gracilis. Appl. Microbiol. Biotechnol. 58:532-538.

Ohnishi, N., Mukherjee, B., Tsujikawa, T., Yanase, M., Nakano, H., Moroney, J. V. \& Fukuzawa, H. 2010. Expression of a Low $\mathrm{CO}_{2}$-inducible protein, $\mathrm{LCI}_{1}$, increases inorganic carbon uptake in the green alga Chlamydomonas reinhardtii. Plant Cell 22:3105-3117.

Pehlivanoglu, E. \& Sedlak, D. L. 2004. Bioavailability of wastewater-derived organic nitrogen to the alga Selenastrum capricornutum. Water Res. 38:3189-3196.

Perez-Garcia, O. \& Bashan, Y. 2015. Microalgal heterotrophic and mixotrophic culturing for bio-refining: from metabolic routes to techno-economics. In Prokop, A., Bajpai, R. K. \& Zappi, M. E. (Eds.) Algal Biorefineries. Springer, Cham, pp. 61-131.

Perez-Garcia, O., Escalante, F. M. E., de-Bashan, L. E. \& Bashan, Y. 2011. Heterotrophic cultures of microalgae: metabolism and potential products. Water Res. 45:11-36.

Perron, M. -C. \& Juneau, P. 2011. Effect of endocrine disrupt- 
ers on photosystem II energy fluxes of green algae and cyanobacteria. Environ. Res. 111:520-529.

Pittman, J. K., Dean, A. P. \& Osundeko, O. 2011. The potential of sustainable algal biofuel production using wastewater resources. Bioresour. Technol. 102:17-25.

Pollock, S. V., Prout, D. L., Godfrey, A. C., Lemaire, S. D. \& Moroney, J. V. 2004. The Chlamydomonas reinhardtii proteins Ccp1 and Ccp2 are required for long-term growth, but are not necessary for efficient photosynthesis, in a low- $\mathrm{CO}_{2}$ environment. Plant Mol. Biol. 56:125-132.

Prajapati, S. K., Choudhary, P., Malik, A. \& Vijay, V. K. $2014 a$. Algae mediated treatment and bioenergy generation process for handling liquid and solid waste from dairy cattle farm. Bioresour. Technol. 167:260-268.

Prajapati, S. K., Kaushik, P., Malik, A. \& Vijay, V. K. $2013 a$. Phycoremediation and biogas potential of native algal isolates from soil and wastewater. Bioresour. Technol. 135:232-238.

Prajapati, S. K., Kaushik, P., Malik, A. \& Vijay, V. K. 2013b. Phycoremediation coupled production of algal biomass, harvesting and anaerobic digestion: possibilities and challenges. Biotechnol. Adv. 31:1408-1425.

Prajapati, S. K., Kumar, P., Malik, A. \& Vijay, V. K. 2014b. Bioconversion of algae to methane and subsequent utilization of digestate for algae cultivation: a closed loop bioenergy generation process. Bioresour. Technol. 158:174-180.

Ramanan, R., Kim, B. -H., Cho, D. -H., Oh, H. -M. \& Kim, H. -S. 2016. Algae-bacteria interactions: evolution, ecology and emerging applications. Biotechnol. Adv. 34:14-29.

Rawat, I., Kumar, R. R., Mutanda, T. \& Bux, F. 2011. Dual role of microalgae: phycoremediation of domestic wastewater and biomass production for sustainable biofuels production. Appl. Energy 88:3411-3424.

Sattayatewa, C., Arnaldos, M. \& Pagilla, K. 2011. Measurement of organic nitrogen and phosphorus fractions at very low concentrations in wastewater effluents. Water Environ. Res. 83:675-683.

Sattayatewa, C., Pagilla, K., Pitt, P., Selock, K. \& Bruton, T. 2009. Organic nitrogen transformations in a 4-stage Bardenpho nitrogen removal plant and bioavailability/ biodegradability of effluent DON. Water Res. 43:45074516.

Seitzinger, S. P. \& Sanders, R. W. 1997. Contribution of dissolved organic nitrogen from rivers to estuarine eutrophication. Mar. Ecol. Prog. Ser. 159:1-12.

Seitzinger, S. P. \& Sanders, R. W. 1999. Atmospheric inputs of dissolved organic nitrogen stimulate estuarine bacteria and phytoplankton. Limnol. Oceanogr. 44:721-730.

Semple, K. T., Cain, R. B. \& Schmidt, S. 1999. Biodegradation of aromatic compounds by microalgae. FEMS Microbiol. Lett. 170:291-300.

Serejo, M. L., Posadas, E., Boncz, M. A., Blanco, S., GarcíaEncina, P. \& Muñoz, R. 2015. Influence of biogas flow rate on biomass composition during the optimization of biogas upgrading in microalgal-bacterial processes. Environ. Sci. Technol. 49:3228-3236.

Sforza, E., Cipriani, R., Morosinotto, T., Bertucco, A. \& Giacometti, G. M. 2012. Excess $\mathrm{CO}_{2}$ supply inhibits mixotrophic growth of Chlorella protothecoides and Nannochloropsis salina. Bioresour. Technol. 104:523-529.

Shen, Y. -F., Liu, L., Gong, Y. -X., Zhu, B., Liu, G. -L. \&Wang, G. -X. 2014. Potential toxic effect of trifloxystrobin on cellular microstructure, mRNA expression and antioxidant enzymes in Chlorella vulgaris. Environ. Toxicol. Pharmacol. 37:1040-1047.

Shi, W., Wang, L., Rousseau, D. P. L. \& Lens, P. N. L. 2010. Removal of estrone, $17 \alpha$-ethinylestradiol, and $17 \beta$-estradiol in algae and duckweed-based wastewater treatment systems. Environ. Sci. Pollut. Res. 17:824-833.

Shi, X. -M., Zhang, X. -W. \& Chen, F. 2000. Heterotrophic production of biomass and lutein by Chlorella protothecoides on various nitrogen sources. Enzyme Microb. Technol. 27:312-318.

Simsek, H., Kasi, M., Wadhawan, T., Bye, C., Blonigen, M. \& Khan, E. 2012. Fate of dissolved organic nitrogen in two stage trickling filter process. Water Res. 46:5115-5126.

Sinetova, M. A., Kupriyanova, E. V., Markelova, A. G., Allakhverdiev, S. I. \& Pronina, N. A. 2012. Identification and functional role of the carbonic anhydrase Cah3 in thylakoid membranes of pyrenoid of Chlamydomonas reinhardtii. Biochim. Biophys. Acta Bioenerg. 1817:12481255.

Singh, S. P. \& Singh, P. 2014. Effect of $\mathrm{CO}_{2}$ concentration on algal growth: a review. Renew. Sustain. Energy Rev. 38:172179.

Solovchenko, A. \& Khozin-Goldberg, I. 2013. High- $\mathrm{CO}_{2}$ tolerance in microalgae: possible mechanisms and implications for biotechnology and bioremediation. Biotechnol. Lett. 35:1745-1752.

Soupene, E., Inwood, W. \& Kustu, S. 2004. Lack of the Rhesus protein Rh1 impairs growth of the green alga Chlamydomonas reinhardtii at high $\mathrm{CO}_{2}$. Proc. Natl. Acad. Sci. U. S. A. 101:7787-7792.

Soupene, E., King, N., Feild, E., Liu, P., Niyogi, K. K., Huang, C. -H. \& Kustu, S. 2002. Rhesus expression in a green alga is regulated by $\mathrm{CO}_{2}$. Proc. Natl. Acad. Sci. U. S. A. 99:77697773.

Subashchandrabose, S. R., Ramakrishnan, B., Megharaj, M., Venkateswarlu, K. \& Naidu, R. 2013. Mixotrophic cyano- 
bacteria and microalgae as distinctive biological agents for organic pollutant degradation. Environ. Int. 51:5972.

Suzuki, T. \& Yamaya, S. 2005. Removal of hydrocarbons in a rotating biological contactor with biodrum. Process Biochem. 40:3429-3433.

Tang, D., Han, W., Li, P., Miao, X. \& Zhong, J. 2011. $\mathrm{CO}_{2}$ biofixation and fatty acid composition of Scenedesmus obliquus and Chlorella pyrenoidosa in response to different $\mathrm{CO}_{2}$ levels. Bioresour. Technol. 102:3071-3076.

Tang, X., He, L. Y., Tao, X. Q., Dang, Z., Guo, C. L., Lu, G. N. \& Yi, X. Y. 2010. Construction of an artificial microalgalbacterial consortium that efficiently degrades crude oil. J. Hazard. Mater. 181:1158-1162.

Thomas, D. N. \& Dieckmann, G. S. 2002. Antarctic sea ice: a habitat for extremophiles. Science 295:641-644.

Ueno, R., Wada, S. \& Urano, N. 2006. Synergetic effects of cell immobilization in polyurethane foam and use of thermotolerant strain on degradation of mixed hydrocarbon substrate by Prototheca zopfii. Fish. Sci. 72:1027-1033.

Ueno, R., Wada, S. \& Urano, N. 2007. Repeated batch cultivation of the hydrocarbon-degrading, micro-algal strain Prototheca zopfii RND16 immobilized in polyurethane foam. Can. J. Microbiol. 54:66-70.

Urgun-Demirtas, M., Sattayatewa, C. \& Pagilla, K. R. 2008. Bioavailability of dissolved organic nitrogen in treated effluents. Water Environ. Res. 80:397-406.

Vähätalo, A. V. \& Järvinen, M. 2007. Photochemically produced bioavailable nitrogen from biologically recalcitrant dissolved organic matter stimulates production of a nitrogen-limited microbial food web in the Baltic Sea. Limnol. Oceanogr. 52:132-143.

Vähätalo, A. V. \& Zepp, R. G. 2005. Photochemical mineralization of dissolved organic nitrogen to ammonium in the Baltic Sea. Environ. Sci. Technol. 39:6985-6992.

Van Den Hende, S., Vervaeren, H., Desmet, S. \& Boon, N. 2011. Bioflocculation of microalgae and bacteria combined with flue gas to improve sewage treatment. New Biotechnol. 29:23-31.

Vandenbruwane, J., De Neve, S., Qualls, R. G., Salomez, J. \& Hofman, G. 2007. Optimization of dissolved organic nitrogen (DON) measurements in aqueous samples with high inorganic nitrogen concentrations. Sci. Total Environ. 386:103-113.

Vanelslander, B., Pohnert, G., Sabbe, K. \& Vyverman, W. 2011. Chemical warfare between microalgae: biogenetic bromine cyanide $(\mathrm{BrCN})$ controls biofilm formation around a marine benthic diatom. In Mees, J. \& Seys, J. (Eds.) VLIZ Young Marine Scientists' Day. Vlaams Instituut voor de Zee (VLIZ), Oostende, p. 102.

Vymazal, J. \& Březinová, T. 2015. The use of constructed wetlands for removal of pesticides from agricultural runoff and drainage: a review. Environ. Int. 75:11-20.

Wang, B., Li, Y., Wu, N. \& Lan, C. Q. 2008. $\mathrm{CO}_{2}$ bio-mitigation using microalgae. Appl. Microbiol. Biotechnol. 79:707718.

Wang, S. -K., Stiles, A. R., Guo, C. \& Liu, C. -Z. 2014. Microalgae cultivation in photobioreactors: an overview of light characteristics. Eng. Life Sci. 14:550-559.

Wang, Y., Duanmu, D. \& Spalding, M. H. 2011. Carbon dioxide concentrating mechanism in Chlamydomonas reinhardtii: inorganic carbon transport and $\mathrm{CO}_{2}$ recapture. Photosynth. Res. 109:115-122.

Wasi, S., Tabrez, S. \& Ahmad, M. 2013. Use of Pseudomonas spp. for the bioremediation of environmental pollutants: a review. Environ. Monit. Assess. 185:8147-8155.

Xia, J. -R. \& Gao, K. -S. 2005. Impacts of elevated $\mathrm{CO}_{2}$ concentration on biochemical composition, carbonic anhydrase, and nitrate reductase activity of freshwater green algae. J. Integr. Plant Biol. 47:668-675.

Yang, C., Hua, Q. \& Shimizu, K. 2000. Energetics and carbon metabolism during growth of microalgal cells under photoautotrophic, mixotrophic and cyclic light-autotrophic/dark-heterotrophic conditions. Biochem. Eng. J. 6:87-102.

Yang, W., Catalanotti, C., Wittkopp, T. M., Posewitz, M. C. \& Grossman, A. R. 2015. Algae after dark: mechanisms to cope with anoxic/hypoxic conditions. Plant J. 82:481503.

Zhang, S., Qiu, C. B., Zhou, Y., Jin, Z. P. \& Yang, H. 2011. Bioaccumulation and degradation of pesticide fluroxypyr are associated with toxic tolerance in green alga Chlamydomonas reinhardtii. Ecotoxicology 20:337-347.

Zhang, Y., Habteselassie, M. Y., Resurreccion, E. P., Mantripragada, V., Peng, S., Bauer, S. \& Colosi, L. M. 2014. Evaluating removal of steroid estrogens by a model alga as a possible sustainability benefit of hypothetical integrated algae cultivation and wastewater treatment systems. ACS Sustain. Chem. Eng. 2:2544-2553.

Zhou, G. -J., Peng, F. -Q., Yang, B. \& Ying, G. -G. 2013. Cellular responses and bioremoval of nonylphenol and octylphenol in the freshwater green microalga Scenedesmus obliquus. Ecotoxicol. Environ. Saf. 87:10-16. 